\title{
PEMBERDAYAAN MASYARAKAT PETANI PALA DENGAN OPTIMALISASI DEFACT BUAH PALA MENJADI PRODUK YANG MEMILIKI NILAI EKONOMI YANG TINGGI
}

\section{EMPOWERMENT OF PALA FARMERS WITH THE OPTIMIZATION OF THE PALA FRUIT BECOME A PRODUCT THAT HAS A HIGH ECONOMIC VELUE}

\author{
R Trihaditia1a, R T D Jatmika1 , A A Imansyah1, RMalia1 \\ ${ }^{1}$ Program Agroteknologi, Fakultas Sains Terapan, Universitas Suryakancana, Jl Pasir Raya, \\ Bojongherang, Cianjur, Bojongherang, Kec. Cianjur, Kabupaten Cianjur, Jawa Barat 43216. \\ aKorespondensi: Riza Trihaditia; E-mail: rizatrihaditia@unsur.ac.id, \\ (Diterima: 16-09-2019; Ditelaah: 17-09-2019; Disetujui: 02-10-2019)
}

\begin{abstract}
The background to our dedication is that Cianjur Regency is one of the potential spices producing regions, one of which is nutmeg. land area used for nutmeg plantations in Cianjur regency is $321 \mathrm{Ha}$ with a production of 84 tons/yr and a productivity level of $549 \mathrm{~kg} / \mathrm{ha}$, but of the many that are taken are nutmegs while nutmeg is useless, it is of little use value. The purpose of this PPUD (Regional Leading Product Development) Community service program activity is to optimize the nutmeg crop yields, especially in parts of nutmeg meat that are deemed defact and become post-harvest waste. The methods used for this service are: (1) Focus Group Discussion, (2) Technical Guidance, (3) Counseling, (4) Mentoring. Where it includes material on food processing, financial management, post-harvest techniques, food diversification, labeling, licensing, marketing strategies. The result of this PPUD community service activity is the presence of a regional superior product that has been developed, namely "Cisara" nutmeg, where the product is the result of the overall community service activity that utilizes nutmeg waste (defact). The conclusion of this community service activity is to conduct PPUD community service activities are using FGD methods, Technical Guidance, Counseling and Assistance and materials on diversification of food preparations, participants of nutmeg farmers and SMEs are very enthusiastic and have made new business opportunities with the cheapest raw materials.
\end{abstract}

Keywords : Community Service, PPUD, Wedang Pala, Cisara.

\begin{abstract}
ABSTRAK
Hal yang melatarbelakangi kami melakukan pengabdian adalah Kabupaten Cianjur merupakan salah satu daerah penghasil rempah yang potensial, salah satunya buah pala. Luas area lahan yang dipakai untuk perkebunan pala di kabupaten Cianjur yaitu $321 \mathrm{Ha}$ dengan produksi 84 ton/th dan tingkat produktivitas $549 \mathrm{~kg} / \mathrm{Ha}$, akan tetapi dari sekian banyak itu yang terambil adalah biji pala sementara daging buah pala terbuang percuma, sangatlah minim nilai pemanfaatannya. Tujuan kegiatan program pengabdian PPUD (Pengembangan Produk Unggulan Daerah) ini adalah untuk mengoptimalisasi hasil panen pala terutama pada bagian daging buah pala yang dianggap defact dan menjadi limbah pasca panen. Metode yang digunakan untuk kegiatan pengabdian ini adalah: (1) Focus Group Discussion, (2) Bimbingan Teknis, (3) Penyuluhan, (4) Pendampingan. Dimana di dalamnya meliputi materi tentang pengolahan pangan, manajemen keuangan, teknik pasca panen, diversifikasi pangan, labelling, perijinan, strategi pemasaran. Hasil dari kegiatan pengabdian PPUD ini adalah adanya produk unggulan daerah yang telah dikembangkan yaitu wedang pala "Cisara" dimana produk tersebut adalah hasil dari keseluruhan kegiatan pengabdian yang memanfaatkan limbah/buangan defact daging pala. Kesimpulan dari kegiatan pengabdian ini adalah dengan melakukan kegiatan pengabdian PPUD menggunakan metode
\end{abstract}


FGD, Bimbingan Teknis, Penyuluhan dan Pendampingan dan materi tentang diversifikasi olahan pangan, peserta petani dan UKM Pala sangat antusias dan telah dijadikannya peluang usaha baru dengan bahan baku yang termurah.

96Kata kunci : Pengabdian, PPUD, Wedang Pala, Cisara.

Trihaditia, R., \& Jatnika, R. T. D., Imansyah, A. A \& Malia, R. (2019). Pemberdayaan Masyarakat Petani Pala Dengan Optimalisasi Defact Buah Pala Menjadi Produk yang Memiliki Nilai Ekonomi yang Tinggi. Jurnal Qardhul Hasan; Media Pengabdian kepada Masyarakat, 5(2), 115-120.

\section{PENDAHULUAN}

Kabupaten Cianjur secara geografis terletak pada koordinas $106^{\circ} 42^{\prime}-107^{\circ} 25^{\prime}$ Bujur Timur dan $6^{\circ} 21^{\prime}-7^{\circ} 25^{\prime}$ Lintang Selatan, dengan ketinggian 7-2.962 mdpl dan memiliki kemiringan $0-40 \%$. Wilayah Kabupaten Cianjur terdiri dari 32 kecamatan dengan luas wilayah 361.434,98 ha dan kecamatan yang memiliki wilayah terluas adalah kecamatan Cidaun dengan luas 29.551,23 ha. Luas lahan di kabupaten Cianjur tahun 2015 adalah 350.148 ha yang terdiri dari lahan sawah dan lahan bukan sawah. Di wilayah Cianjur Tengah tumbuh dengan baik tanaman padi, kelapa dan buah-buahan. Kabupaten Cianjur merupakan salah satu daerah penghasil rempah yang potensial, salah satunya buah pala. luas area lahan yang dipakai untuk perkebunan pala di kabupaten Cianjur yaitu 321 ha dengan produksi 84 ton/th dan tingkat produktivitas $549 \mathrm{~kg} / \mathrm{Ha}$. Dengan potensi perkebunan yang ada memiliki beberapa hal yang dapat melemahkan potensi, salah satunya adalah kejenuhan pasar akan hasil akhir dari pasca panen pala. Sejauh ini para petani pala di cianjur mencapai $1.239 \mathrm{kk}$ dengan produktivitas sebesar $549 \mathrm{~kg} /$ Ha dan produksinya sebesar 84 ton dengan luas lahan 153 meter persegi. Para petani pala mengeluhkan barang defect dari pala yang tidak dapat terjual di pasaran. Karena buah pala dengan kecacatan tidak dapat diterima oleh pasaran. Selama ini barang defect pala biasanya terbuang percuma oleh para petani. Selain itu mereka mengeluhkan kurangnya sosialisasi dan bimbingan teknik dari pemerintah untuk mensejahterakan kelompok tani di daerah setempat. Minimnya pengetahuan petani tentang diversifikasi produk dari buah pala juga menjadi kendala dari sisi ekonominya. Karena barang defect ini sebenarnya dapat diolah lagi menjadi minuman yang dapat menjadi nilai tambah ekonomi bagi para petani pala. Diperlukan pelatihan dan pendampingan kepada para petani untuk dapat mengolah dan membuat diversifikasi produk dari buah pala untuk menanggulangi buah pala defact yang tidak dapat diterima di pasaran. Buah pala merupakan salah satu tumbuhan khas Indonesia, khususnya di Kecamatan Warungkondang Kabupaten Cianjur Jawa barat, yang memiliki nilai jual dan memberikan manfaat untuk kesehatan, namun minimnya pengetahuan produsen dalam pengolahan produk buah pala, yang hanya sebatas membuat manisan dan bumbu rempah saja. Pala (Myristica fragrans Houtt.) merupakan salah satu tanaman asli Indonesia yang berasal dari Kepulauan Maluku.[5] Tanaman ini telah tersebar di seluruh wilayah Indonesia dengan luas areal tahun 2017 mencapai 169.587 ha dengan produksi 34.602 ton. Volume ekspor pala Indonesia tahun 2016 sebesar 11.549 ton dengan nilai US\$ 64.398. Indonesia juga melakukan impor pala tapi jumlahnya relatif kecil, pada tahun 2016 volume impor pala sebesar 82 ton dengan nilai US\$ 766, turun dibanding volume impor tahun 2015 yang mencapai 92 ton dengan nilai US\$ 948. Jawa Barat merupakan daerah pengembangan tanaman pala. Areal yang sudah eksis di daerah ini mencapai 6.253 ha dengan produksi 1.056 ton. Untuk Cianjur sendiri luas areal yang di gunakan untuk produksi pala yaitu, $321 \mathrm{H}$ dengan produsksi 84 ton dan produkstifitas sebesar $549 \mathrm{~kg} / \mathrm{h}$.[6] Minuman fungsional 
adalah jenis pangan fungsional yang mengandung unsur-unsur zat gizi atau non zat gizi dan jika dikonsumsi dapat memberikan pengaruh positif terhadap kesehatan tubuh. Minuman fungsional merupakan jenis pangan atau produk pangan yang memiliki ciri-ciri fungsional sehingga berperan dalam perlindungan atau pencegahan, pengobatan terhadap penyakit, peningkatan kinerja fungsi tubuh optimal, dan memperlambat proses penuaan.[7] Minuman fungsional dapat dibuat dari berbagai macam tanaman, salah satu tanaman yang dapat diolah menjadi minuman fungsional adalah benalu kopi (Loranthus parasitiku). Minuman fungsional harus dapat memenuhi dua fungsi utama dari pangan yaitu, memberikan asupan gizi serta pemuasan sensori seperti rasa yang enak dan tekstur yang baik. Minuman fungsional dilengkapi dengan fungsi tersier seperti probiotik, menambah asupan vitamin dan mineral tertentu, meningkatkan stamina tubuh dan juga mengurangi resiko penyakit tertentu seperti, antioksidan untuk mengurangi.

\section{MATERI DAN METODE}

Pola pembinaan yang dilakukan adalah pola penyuluhan dan pembinaan langsung dimana pelaku pengabdian ini melakukan bimbingan teknis dari mulai on farm sampai ke off farm. Sebelum dimulai bimbingan teknis, diadakan FGD (Focus Group Discussion) untuk mengetahui apa saja kendala yang dihadapi oleh; stakeholders, BUMDes, Desa, Investor agrowisata, dan UKM sebanyak 20 orang dimana 8 orang dari pihak Universitas Suryakancana dan 12 orang lagi dengan pihak yang bersangkutan. Adapun materi yang diberikan pada pengabdian PPUD Cisarandi ini meliputi: Budidaya Tanaman Pala; Strategi Pemasaran; Manajemen Keuangan; Pengolahan Pangan; Diversifikasi Olahan Pala; Perijinan UKM; Kemasan dan Labelling; Metode yang digunakan dalam penyampaian materi diatas yaitu dengan cara: Bimbingan Teknis (Bimtek); Penyuluhan; Pendampingan; Seminar.

\section{HASIL DAN PEMBAHASAN}

Kegiatan pengabdian PPUD ini bersifat multiyear, kegiatan ini dilaksanakan selama 3 (tiga) tahun dan setiap tahunnya kami buat jurnal pengabdian. Target utama dalam pengabdian PPUD secara keseluruhan ini adalah:Mengoptimalkan nilai ekonomi pada produk yang tidak layak dipasarkan menjadi layak dipasarkan; Mengoptimalkan penganekaragaman produk olahan pala; Mengoptimalkan potensi sumber daya alam dan sumber daya manusia; Meningkatkan kesejahteraan masyarakat terutama bagi petani dan pengrajin/pelaku; UKM di daerah kecamatan warungkondang selaku daerah potensi produk pala; Membuat produk ciri khas dari daerah yang mempunyai nilai jual dan ke khasan untuk tahun pertama ini dimulai dari bulan februari dan berakhir dipertengahan bulan agustus. Dimana rangkaian skema kegiatannya meliputi.

\section{Pemetaan}

Pada tahapan ini para peserta pengabdian yang terdiri dari 4 orang Dosen dan 4 orang Mahasiswa melakukan obeservasi lapangan, dimana kegiatan ini bertujuan untuk bahan analisis SWOT yang akan digunakan sebagai referensi pengambilan keputusan dan mengumpulkan data untuk diolah dengan teori fishbone. Data-data yang dikumpulkan meliputi:Budidaya tanaman pala; Pasca panen tanaman pala; Kondisi Geografis dan Demografis (Petani pala dan Pengrajin/UKM Pala);BUMDes. Kegiatan ini dilakukan pada awal bulan februari 2019, tim yang beranggotakan 8 (delapan) orang ini dibagi menjadi 2 (dua) kelompok yang masing-masing kelompok beranggotakan 2 (dua) orang Dosen dan 2 (dua) orang Mahasiswa. Tim A memiliki tugas mengumpulkan informasi dan data yang sifatnya pertanian atau yang erat hubungannya dengan pertanian, sedangkan tim B memiliki tugas yaitu mengumpulkan 
informasi dan data non pertanian atau yang sifatnya umum.

\section{FGD}

Focus Group Discussion ini adalah rangkaian kedua pengabdian dimana para peserta pengabdian yang terdiri dari 4 (empat) dosen dan 4 (empat) mahasiswa H-10 berembuk untuk menentukan materi yang akan dibahas. Adapun hasil dari persiapan menjelang FGD adalah sebagai berikut:Penyampaian dan pemaparan program PPUD (keynote speaker: ketua pengabdian);Penentuan 20 orang peserta yang diundang; Penentuan waktu dan tempat FGD; Persiapan lain-lain. Pelaksanaan FGD diselenggarakan di balai desa Cisarandi pada hari Selasa tanggal 23 April 2019, dengan peserta dari berbagai kalanga yaitu akademisi, aparatur desa, petani dan pengrajin pala. Materi yang di paparkan yaitu tentang hasil pemetaan dan pemaparan program PPUD yang terfokuskan pada pemanfaatan limbah dan defact dari hasil pertanian pala.

Hasil dari kegiatan FGD ini adalah terdapat kesefahaman untuk dapat memaksimalkan produk pala dan komoditas turunannya. Selain itu juga ada kesepakatan antara aparatur desa, petani dan pengrajin untuk dapat mengelola usaha wedang pala ini yang terpusat di BUMDes Sabilulungan dan juga akan menyegerakan pembuatan PERDES yang didalamnya tertuang tentang hilirisasi industri pala dimana masyarakat dianjurkan membeli di acara perhelatan tingkat Desa serta untuk mendukung usaha wedang pala ini para petani tidak boleh menjual daging pala keluar desa Cisarandi.

\section{Bimbingan Teknis}

Bimbingan Teknis merupakan kegiatan pelatihan dan pengembangan pengetahuan serta kemampuan yang dapat digunakan untuk memecahkan masalah yang dihadapi oleh setiap individu maupun institusi tertentu. Bimbingan Teknis ini diselenggarakan pada tanggal 03 Mei 2019 dimana peserta yang hadir berjumlah 25 orang bertempat di balai Desa Cisarandi, materi yang dipaparkan adalah materi tentang perubahan mindset peserta khususnya para petani dan pengrajin pala agar bisa berinovasi dan berkreasi, sehingga diharapkan peserta terstimulasi pemikirannya. Materi praktek pembuatan wedang pala adalah materi utama yang digagas dalam kegiatan pengabdian PPUD ini, dimana wedang pala dibuat dari bahan baku yang dibuang akan tetapi kami olah dan menjadi produk komersil dan memiliki nilai tambah yang lebih banyak dari produk olahan pala lainnya.

\section{Penyuluhan}

Kegiatan penyuluhan ini dilakukan di daerah Warungkondang, dimulai dari On Farm yaitu cara pembibitan tanaman pala, cara pemeliharaan tanaman pala dan pemanenan yang meliputi pra panen dan pasca panen. dan dilakukannya bimbingan teknis bagi masyarakat pelaku UKM manisan pala atau wirausahawan baru tentang pengolahan pangan yang terimplementasi dalam kegiatan pelatihan Cara Penanganan Produk Olahan yang Baik (CPPOB/GMP) tentang minuman fungsional dari pala (Minuman Wedang Pala) yang merupakan bagian dari penyuluhan off Farm. kegiatan ini mempunyai tujuan utamanya yaitu pemberdayaan sumber daya manusia yang merupakan pokok permasalahan yang selama ini timbul. Kegiatan penyuluhan ini dilakukan selama lima hari dengan materi diantaranya:28 Juni 2019 penyuluhan tentang Strategi Pemasaran; 29 Juni 2019 Penyuluhan tentang Diversifikasi Olahan Pala; 01 Juli 2019 Penyuluhan tentang Manajemen Keuangan; 04 Juli 2019 Penyuluhan tentang Labelling, Pengemasan dan Perijinan; 06 Juli 2019 Penyuluhan tentang Praktek Pembuatan Wedang pala. Adapun bukti pelengkap lainnya kami sajikan dilampiran diantaranya laporan kegiatan dimasingmasing hari kegiatan penyuluhan

\section{Pendampingan}

Pada kegiatan pendampingan ini dilakukan untuk mengawal hasil dari penyuluhan, 
pendampingan dilakukan 8 (delapan) hari berturut-turut, dimulai tanggal 01 Agustus samapai dengan 08 Agustus 2019. Pendampingan ini dilakukan oleh 8 orang pendamping yang terdiri dari dosen dan mahasiswa, dimana pendampingan ini dilakukan dengan metode rumah ke rumah produksi. Dimana pendamping ini lebih fokus pada 1 UKM saja. Masing-masing pendamping memegang kartu kendali "Progress Report" dimana fungsinya adalah: pelaporan; daftar hadir/kunjungan; dokumentasi kegiatan.

Materi pendampingan disesuaikan tugas masing-masing pendamping, materi diantaranya membahas tentang: SDM; Manajemen Keuangan; Promosi/Strategi Pemasaran; Pengolahan Pangan; Legalitas Kemasan; Labelling; Pasca Panen; Budidaya Pala; E. Commerce; Branding. Adapun bukti pelengkap lainnya kami sajikan dilampiran diantaranya laporan kegiatan dimasingmasing hari kegiatan pendampingan yang tertuang pada progress report pendamping.

\section{KESIMPULAN}

\section{Kesimpulan}

Kegiatan Pengabdian ini dilakukan baru 1(satu) tahun berjalan dari total keseluruhan 3(tiga) tahun, hasil yang telah dirasakan oleh masyarakat Desa Cisarandi, Kec. Warung kondang, Kab. Cianjur Jawa Barat ini adalah telah berubahnya pola pikir dan pengetahuan masyarakat tentang bahan yang terbuang menjadi bahan yang memiliki nilai ekonomis yang tinggi. Dengan biaya produksi (HPP) sekitar Rp. 3.450 dapat mengangkat produk yang memiliki nilai jual Rp 10.000,-. Melalui metode Bimbingan Teknis, Penyuluhan serta Pendampingan secara simultan dan berkesinambungan, masyarakat Desa Cisarandi merasa usaha yang sekarang mereka lakukan ada yang membina mulai dari tata cara pemilihan bahan, proses produksi, manajemen keuangan, pemasaran, labelling dan perijinan. Perubahan pola pikir adalah hal yang utama ,untuk merubah pola pikir masyarakat Desa Cisarandi diperlukan pendampingan yang intensif dan pembuktian yang faktual.

\section{Saran}

Untuk keberlangsungan kegiatan PPUD ini dibutuhkan peran pemerintahan Daerah yang sangat aktif , bukan hanya memfasilitasi kegiatan ini akan tetapi mendukung dengan cara meberikan koneksi pemasaran dan diikutsertakan dalam segala macam kegiatan seperti pameran dan bazar. Ujung dari kegiatan ini adalah di tahun ke-3, diharapkan kegiatan ini masih bisa berjalan ditahun berikutnya dan mendapatkan didukung penuh oleh Kemenristekdikti, Universitas dalam rangka pemenuhan Sumber Daya Manusia (pelaksana Pengabdian).

\section{DAFTAR PUSTAKA}

https://cianjurkab.go.id/profilcianjur/letak geografis/

http://jabarprov.go.id/index.php/pages/id/ $\underline{103}$

https://cianjur.pojoksatu.id/baca/petani cianjur-wajib-punya-kartu-tani-inisyaratnya

http://ditjenbun.pertanian.go.id/tinymcpuk /gambar/file/statistik/2017/Pala2015-2017.pdf

Hadad, E.A., A. Hamid. 1990. Mengenal berbagai plasma nutfah pala di daerah Maluku Utara. Balai Penelitian Tanaman Rempah dan Obat, Bogor.

http://ditjenbun.pertanian.go.id/tinymcpuk /gambar/file/statistik/2017/Pala 2015-2017.pdf

Sampoerno \& D. Fardiaz. 2001. Kebijakan dan Pengembangan Pangan 
Funsional dan Suplemen di Herawati $\mathrm{N}$ et all, Pembuatan minuman Indonesia dalam L. Nuraida \& R.D. fungsional berbasis ekstrak kulit buah Hariyadi (Eds), Proceeding Seminar naga merah (hylocereus polyrhizus), Nasional Pangan Tradisional sebagai Basis Industri Pangan Fungsional dan Suplemen Pusat Kajian Makanan Tradisional. Rosela (Hibiscus sabdariffa L.) dan Buah Salam (Syzygium polyanthum wigh walp). 